\title{
Review \\ Historical Perspective of the G Protein-Coupled Receptor Kinase Family
}

\author{
Jeffrey L. Benovic
}

check for

updates

Citation: Benovic, J.L. Historical Perspective of the G Protein-Coupled Receptor Kinase Family. Cells 2021, 10, 555. https://doi.org/ 10.3390/cells10030555

Academic Editors: Federico Mayor and Cristina Murga

Received: 10 February 2021

Accepted: 26 February 2021

Published: 4 March 2021

Publisher's Note: MDPI stays neutral with regard to jurisdictional claims in published maps and institutional affiliations.

Copyright: (C) 2021 by the author. Licensee MDPI, Basel, Switzerland. This article is an open access article distributed under the terms and conditions of the Creative Commons Attribution (CC BY) license (https:// creativecommons.org/licenses/by/ $4.0 /)$.
Department of Biochemistry and Molecular Biology, Sidney Kimmel Medical College, Thomas Jefferson University, Philadelphia, PA 19107, USA; jeffrey.benovic@jefferson.edu

\begin{abstract}
Agonist activation of G protein-coupled receptors promotes sequential interaction of the receptor with heterotrimeric $G$ proteins, $G$ protein-coupled receptor kinases (GRKs), and arrestins. GRKs play a central role in mediating the switch from $G$ protein to arrestin interaction and thereby control processes such as receptor desensitization and trafficking and arrestin-mediated signaling. In this review, I provide a historical perspective on some of the early studies that identified the family of GRKs with a primary focus on the non-visual GRKs. These studies included identification, purification, and cloning of the $\beta$-adrenergic receptor kinase in the mid- to late-1980s and subsequent cloning and characterization of additional members of the GRK family. This helped to lay the groundwork for ensuing work focused on understanding the structure and function of these important enzymes.
\end{abstract}

Keywords: arrestins; GPCR; GRK; phosphorylation; signaling

\section{Introduction}

G protein-coupled receptors (GPCRs) are the largest family of membrane-localized proteins in mammals and function to enable cells to transmit extracellular stimuli such as hormones, chemokines, ions, peptides, and sensory stimuli into intracellular functional changes [1]. GPCRs primarily mediate their effects via the ability to interact in an activationdependent manner with three protein families: heterotrimeric G proteins, GPCR kinases (GRKs), and arrestins. Initial work by the Rodbell and Gilman laboratories led to the discovery of the heterotrimeric G proteins [2], whereas studies in retinal rod cells by several groups led to the initial discovery of GRKs and arrestins. Subsequent work in the Lefkowitz and Caron laboratories led to the initial identification of non-visual GRKs and arrestins. In this review, I provide a historical overview of the initial discovery and characterization of the GRKs largely from my own personal perspective. This was the primary focus of my research in the Lefkowitz lab in the 1980s as well as a major focus of studies in my own laboratory starting in 1989.

\section{Discovery of Rhodopsin Kinase}

The history of the GRKs began in the 1970s with research in the visual system. Initial work by three groups demonstrated light-dependent phosphorylation of rhodopsin in rod membranes [3-5], whereas additional studies were able to extract a kinase from rod membranes that could phosphorylate photobleached rhodopsin [6]. The kinase was initially named opsin kinase [6] and later rhodopsin kinase (now called GRK1), and it was subsequently purified and found to specifically phosphorylate light-activated rhodopsin $[7,8]$. The latter purification involved salt extraction of rod outer segments followed by sequential fractionation on DE-cellulose 52 and hydroxyapatite resulting in a 1000-fold overall purification and recovery of $50 \mu \mathrm{g}$ of purified kinase from 400 bovine retinas [8]. Properties of rhodopsin kinase include a molecular weight of $67-70 \mathrm{kDa}$, specificity for phosphorylation of photoactivated rhodopsin, and insensitivity to various second messengers, including cAMP, cGMP, and inositol trisphosphate. 


\section{Discovery of the $\beta$-Adrenergic Receptor Kinase ( $\beta$ ARK)}

Studies in the Lefkowitz laboratory during the late 1970s and early 1980s were focused on understanding the mechanisms involved in the loss of responsiveness of $\beta$-adrenergic receptor $(\beta \mathrm{AR})$ signaling following prolonged stimulation with a $\beta$-agonist, a process that was termed desensitization or tachyphylaxis. These studies revealed that the $\beta A R$ underwent a mobility shift on gel electrophoresis following agonist treatment of cells and demonstrated that this shift was due to receptor phosphorylation $[9,10]$. Additional studies established that at least some of this phosphorylation was due to the cAMP-dependent protein kinase (PKA) [11]. Intertwined with our understanding of this process were studies focused on purification of the $\beta$-adrenergic receptor, initially from frog [12] and turkey [13] erythrocytes followed by mammalian tissues such as hamster, rat, and guinea pig lung [14]. The purified hamster $\beta_{2}$-adrenergic receptor $\left(\beta_{2} \mathrm{AR}\right)$ was then fed into three projects: (1) one to reconstitute the receptor into phospholipid vesicles to determine if the purified receptor could directly activate the purified stimulatory heterotrimeric $G$ protein $\left(\mathrm{G}_{\mathrm{s}}\right.$ or $\left.\mathrm{N}_{\mathrm{s}}\right)$ in an agonist-dependent manner [15,16]; (2) one to obtain amino acid sequence to use in cloning a cDNA for the $\beta_{2} \mathrm{AR}$ [17]; and (3) one to better understand the process of receptor desensitization. In regard to the desensitization efforts, in vitro studies demonstrated that PKA could directly phosphorylate the purified $\beta_{2} \mathrm{AR}$ to a stoichiometry of $2 \mathrm{~mol}$ phosphate/mol receptor and that this phosphorylation directly inhibited receptor coupling to $\mathrm{G}_{\mathrm{s}}$, although only $25 \%$ inhibition was observed in these initial studies [18]. Subsequent studies found that PKA phosphorylation of the receptor inhibited $\beta_{2} A R-G_{s}$ coupling by $60 \%$ at physiological concentrations of $\mathrm{Mg}^{2+}$ [19]. Thus, these studies identified a mechanism of feedback regulation that involved phosphorylation of the $\beta_{2} \mathrm{AR}$ by PKA, the protein kinase activated by the $\beta A R$-signaling pathway. While this feedback regulation of the $\beta_{2} A R$ by PKA was termed heterologous or agonist-independent desensitization, one interesting aspect of the in vitro work was that the $\beta_{2}$ AR was found to be a better substrate for PKA in the presence of the agonist [18], suggesting that there may be an agonist-dependent or homologous component to this feedback regulation. To my knowledge, this aspect of the regulation has never been further explored.

While a role for PKA phosphorylation of the $\beta_{2} \mathrm{AR}$ was evident from these early studies, additional efforts revealed that the $\beta_{2} \mathrm{AR}$ could also be phosphorylated in an agonist-dependent manner in $S 49$ lymphoma cell lines that could not activate PKA either because they lacked the ability to produce cAMP (cyc ${ }^{-}$cells) or they lacked the PKA catalytic subunit (kin ${ }^{-}$cells) [20]. This observation led to a search for the enzyme that phosphorylated the $\beta_{2} \mathrm{AR}$ in an agonist-dependent manner and ultimately resulted in the identification of the $\beta$-adrenergic receptor kinase or $\beta$ ARK (now called GRK2) [21]. A critical aspect of this work was the ability to use the purified $\beta_{2} \mathrm{AR}$ as a substrate, which facilitated the demonstration that this was an agonist-dependent process. Indeed, the first successful experiment testing the ability of an S49 $\mathrm{kin}^{-}$cell extract to phosphorylate the purified receptor revealed that phosphorylation was increased in the presence of the $\beta$-agonist isoproterenol and that the agonist effect was blocked by the addition of the $\beta$-antagonist alprenolol (Figure 1).

$\beta$ ARK had clear similarities with rhodopsin kinase in that both enzymes phosphorylated the active form of the receptor. These studies were contiguous with the cloning of a cDNA for the $\beta_{2} \mathrm{AR}$ and, taken together, raised interesting questions about the similarities between phototransduction through rhodopsin and hormonal signaling through the $\beta_{2} A R$ [22]. Indeed, additional studies demonstrated that $\beta$ ARK could phosphorylate lightactivated rhodopsin whereas rhodopsin kinase could phosphorylate the agonist-occupied $\beta_{2} \mathrm{AR}$, albeit with each kinase preferring its endogenous substrate [23]. An additional series of studies suggested that $\beta$ ARK might have broad specificity for GPCRs since activation of the prostaglandin $E_{1}[24]$ or somatostatin [25] receptors promoted $\beta A R K$ translocation from the cytosol to the plasma membrane. Moreover, $\beta$ ARK was also able to directly phosphorylate purified $\alpha_{2}$-adrenergic receptors in an agonist-dependent manner [26]. Taken together, 
these early studies suggested that $\beta$ ARK had a broad specificity and likely regulated the agonist-dependent phosphorylation of many GPCRs.

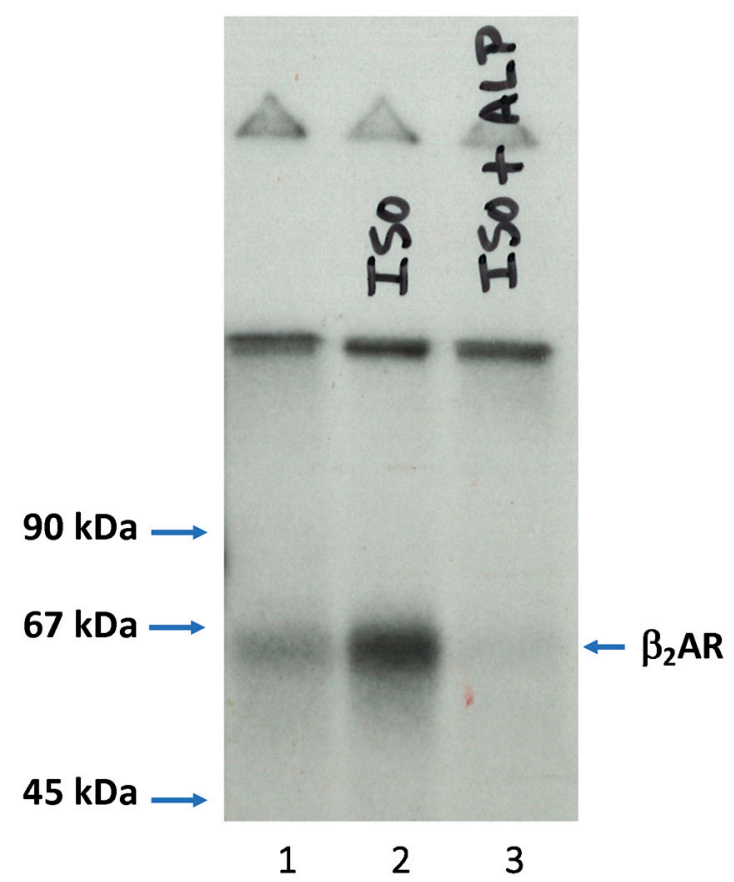

Figure 1. S49 $\mathrm{kin}^{-}$cell extract phosphorylation of purified $\beta_{2} \mathrm{AR}$. S49 lymphoma kin ${ }^{-}$cells were lysed, centrifuged, and the supernatant was incubated with $\mathrm{MgCl}_{2}$, radiolabeled ATP, purified hamster lung $\beta_{2} \mathrm{AR}$ reconstituted in phospholipid vesicles, and either no ligand (lane 1), $10 \mu \mathrm{M}$ isoproterenol (ISO) (lane 2), or $10 \mu \mathrm{M}$ ISO plus $20 \mu \mathrm{M}$ alprenolol (ALP) (lane 3) for $30 \mathrm{~min}$ at $30{ }^{\circ} \mathrm{C}$. The samples were centrifuged, and the pellets were washed, solubilized, and the $\beta_{2} \mathrm{AR}$ was purified on a small alprenolol affinity column and then run on SDS-PAGE and exposed to film.

The next step in this work involved developing strategies to purify $\beta$ ARK. This initially involved searching for a tissue that had a high level of $\beta$ ARK expression with minimal degradation of the enzyme. Analysis of a number of tissues identified bovine cerebral cortex as a good source of the $\beta$ ARK activity (i.e., the ability to phosphorylate purified $\beta_{2} \mathrm{AR}$ in an agonist-dependent manner), whereas tissues such as lung, spleen, liver, and heart had much lower levels of activity [27]. To purify the enzyme, the tissue was homogenized, centrifuged, and an ammonium sulfate cut of the soluble fraction was then purified through Ultrogel AcA34, DEAE-Sephacel, CM-Fractogel, and hydroxylapatite columns. This resulted in an overall purification of 20,000-fold and recovery of $12 \mu \mathrm{g}$ of purified kinase from $100 \mathrm{~g}$ of tissue. Purified $\beta$ ARK was $80 \mathrm{kDa}$, it phosphorylated the agonist-occupied $\beta_{2} \mathrm{AR}$ with a $\mathrm{K}_{\mathrm{m}}$ of $0.25 \mu \mathrm{M}$, and it had many properties similar to rhodopsin kinase.

Once $\beta$ ARK was purified, the next major goal was to clone a cDNA that encoded the protein. While we were able to purify $\beta$ ARK in adequate quantities to obtain amino acid sequence from cyanogen bromide-derived peptides, the subsequent cloning turned out to be an arduous process since all of the commercial cDNA libraries that were screened turned up nothing useful-always some positive clones on screening but never any sequences that matched the sequence of the kinase. So, what was wrong? Was it the amino acid sequence obtained from the purified $\beta$ ARK preparations? Maybe, but three different $\beta$ ARK preparations yielded consistent results, so we were confident in the amino acid sequences we were using to generate the radiolabeled oligonucleotides for screening (Figure 2A). Was it the cDNA libraries we were using? This certainly seemed to be a possibility since the libraries were mainly commercially obtained, and we were searching for something of low abundance. I attempted to address this issue by making my own cDNA library, but this 
again yielded nothing useful. We then turned to Dr. Richard Dixon at Merck Sharp and Dohme Research Laboratories for help since he had played a major role in the cloning of the $\beta_{2}$ AR [17]. Following a phone call from Bob Lefkowitz, Dr. Dixon provided us with a bovine brain cDNA library that he had personally created. The library was screened in February 1989, and we knew that we had bona fide $\beta$ ARK clones that hybridized with multiple probes within 10 days (Figure 2B). I had been screening cDNA libraries for two years at that point, so the level of excitement with the results is hard to describe but certainly in my top 10 list. Several overlapping clones were quickly sequenced and revealed an open reading frame of $2067 \mathrm{bp}$ encoding a 689 amino acid protein [28]. Evidence supporting that the clone encoded $\beta$ ARK included the demonstration that expression in COS-7 cells yielded a protein that could phosphorylate the $\beta_{2} \mathrm{AR}$ in an agonist-dependent manner. Moreover, a Southern blot of Hind III- or Sac I-digested bovine genomic DNA identified several low-stringency hybridizing bands, suggesting the presence of $\beta$ ARK-related genes [28].

A

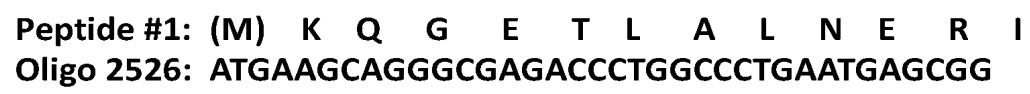

B Oligo:

2526

2288

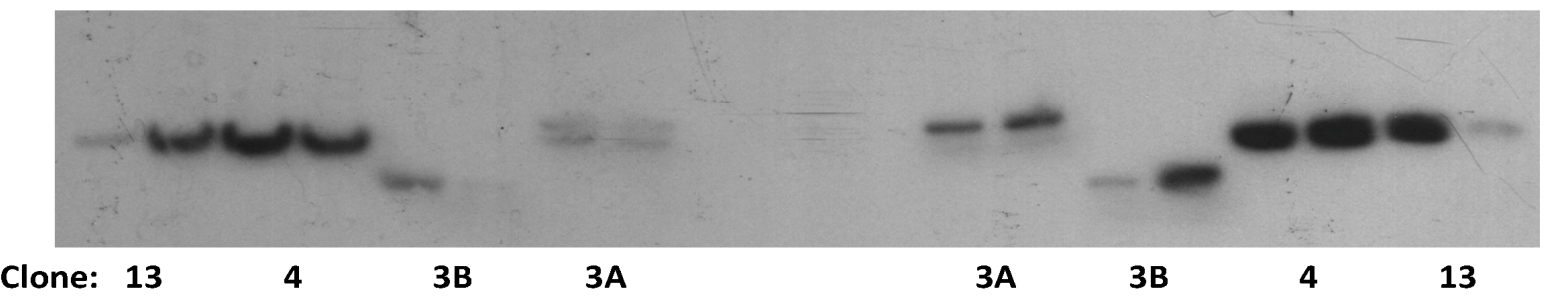

Figure 2. Cloning of a $\beta$-adrenergic receptor kinase ( $\beta$ ARK) cDNA from a bovine brain cDNA library. One nmol of purified $\beta A R K$ was treated with $\mathrm{CNBr}$, and the resulting peptides were separated and sequenced. A total of eight distinct peptide sequences were identified, with two being used in the design of oligonucleotide probes for cloning. (A) Amino acid sequence of two peptides that were consistently observed in multiple $\beta$ ARK preparations and the sequences of the oligonucleotide probes that were used to hybridize with cDNA libraries. The underlined residues in peptide \#2 were found to be incorrect. (B) A Southern blot of several clones (3A, 3B, 4, and 13) isolated from the bovine brain cDNA library using radiolabeled oligo 2526 derived from peptide \#1. Two colonies from each clone were digested with Eco RI, transferred to nitrocellulose, and probed with radiolabeled oligos derived from peptide \#1 (2526) or peptide \#2 (2288). The clones were sequenced, and clones $3 \mathrm{~A}$ and 4 were found to contain a complete open reading frame. I-inosine.

\section{The GRK Family}

Once $\beta$ ARK was cloned, the next major goal was to identify additional members of the family. $\beta$ ARK2 (now called GRK3) was the next member cloned and resulted from low-stringency hybridization studies using the $\beta$ ARK cDNA to probe a bovine brain cDNA library [29]. $\beta$ ARK2 was 688 amino acids and had $85 \%$ amino acid identity to $\beta$ ARK, with the kinase catalytic domain being $95 \%$ identical (Table 1). $\beta$ ARK2 had lower activity against the $\beta_{2} \mathrm{AR}$ and rhodopsin as substrates and tended to be expressed at a lower level in most tissues compared to $\beta$ ARK. 
Table 1. Amino acid homology of human G protein-coupled receptor kinases (GRKs).

\begin{tabular}{cccccccc}
\hline & GRK1 & GRK2 & GRK3 & GRK4 & GRK5 & GRK6 & GRK7 \\
\hline GRK1 & 100 & 52 & 52 & 66 & 69 & 68 & 66 \\
GRK2 & 33.4 & 100 & 92 & 54 & 54 & 55 & 53 \\
GRK3 & 33.5 & 84.0 & 100 & 53 & 53 & 55 & 53 \\
GRK4 & 47.7 & 36.4 & 36.5 & 100 & 81 & 79 & 65 \\
GRK5 & 47.8 & 37.2 & 37.1 & 68.0 & 100 & 84 & 65 \\
GRK6 & 48.2 & 38.7 & 38.9 & 66.6 & 72.3 & 100 & 66 \\
GRK7 & 47.6 & 31.2 & 32.2 & 47.9 & 45.9 & 46.5 & 100 \\
\hline
\end{tabular}

Percent amino acid identity (in black) or similarity (in red) of human GRKs. Pairwise comparisons were conducted using sequences from human GRK1 (563 amino acids, Q15835 from UniProtKB), GRK2 (689 amino acids, P25098), GRK3 (688 amino acids, P35626), GRK4 $\alpha$ (578 amino acids, P32298), GRK5 (590 amino acids, P34947), GRK6A (576 amino acids, P43250), and GRK7 (553 amino acids, Q8WTQ7) using BlastP at blast.ncbi.nlm.nih.gov.

Rhodopsin kinase was the next GRK to be cloned via collaborative efforts between the Palczewski and Lefkowitz laboratories. This involved obtaining amino acid sequences of the purified protein to generate oligonucleotide probes that were used to screen a bovine retina cDNA library. This yielded clones encoding a 561 amino acid protein with 33.5\% overall identity to $\beta$ ARK [30] (Table 1). Interestingly, the C-terminal domain of rhodopsin kinase was much shorter than that of $\beta A R K$ and ended with a CAAX motif suggesting that the protein may be prenylated. Indeed, subsequent studies showed that rhodopsin kinase is farnesylated and that this modification is important for full kinase activity [31]. The fourth member of the family to be cloned was called IT11 (interesting transcript 11, now called GRK4) and was fortuitously cloned as a result of its location near the Huntington's disease locus [32]. The original IT11 clone encoded a 500 amino acid protein and had $48 \%$ overall identity to rhodopsin kinase and $36 \%$ to $\beta$ ARK (Table 1 ). A subsequent study showed that there are four splice variants of GRK4, that expression was primarily limited to the testes, and that the protein was palmitoylated [33].

Efforts from a number of laboratories ultimately led to the cloning and characterization of GRK5 and GRK6. GRK5 was initially cloned by the Benovic laboratory using degenerate oligonucleotides derived from unique GRK regions to amplify human heart cDNA using the polymerase chain reaction (PCR) [34]. GRK5 was 590 amino acids and had the highest amino acid homology with IT11, followed by rhodopsin kinase and BARK (Table 1). GRK5 expression was highest in heart and lung and lowest in brain, liver, and kidney. GRK5 was also cloned from a taste cell cDNA library [35]. It is worth noting that while the first two members of the GRK family were named after their substrate (rhodopsin or $\beta_{2} \mathrm{AR}$ ), the initial study identifying GRK5 recommended that the nomenclature be standardized [34]. The recommendation in the originally submitted manuscript was to use the GPRK nomenclature that had been used for two Drosophila members of the G protein-coupled receptor kinase family that had been identified, GPRK1 and GPRK2 [36]. However, the reviewer of the manuscript recommended the use of GRK instead of GPRK, so this ultimately led to the current naming of the family. The kinases were then named based on their order of discovery with GRK1 for rhodopsin kinase, GRK2 for $\beta$ ARK, GRK3 for $\beta$ ARK2, and GRK4 for IT11.

Additional efforts in the Benovic laboratory used the GRK2 and GRK3 cDNAs to screen a human heart cDNA library by low-stringency hybridization. This yielded the sixth member of the family (GRK6), a 576 amino acid protein with the highest identity to GRK5 and GRK4 [37]. GRK6 had an expression pattern similar to GRK2 with the highest levels in brain and skeletal muscle $>$ heart, lung and kidney $>$ liver. Initial functional studies suggested that GRK6 activity was significantly lower than GRK2, at least using rhodopsin and the $\beta_{2} \mathrm{AR}$ as substrates. GRK6 was also cloned from cDNA prepared from human neutrophils using PCR amplification [38], although this clone appears to be a splice variant since it lacks the region that encodes the N-terminal 32 amino acids found in the GRK6 cloned from the human heart cDNA library. The final mammalian member of the GRK family to be cloned was GRK7 [39,40]. GRK7 cloned from mammalian species by RT-PCR 
was 548 amino acids with expression in cones [39], whereas cloning from medaka yielded a 563 amino acid protein containing a putative C-terminal site for geranylgeranylation [40]. GRK7 is most homologous to GRK1, GRK4, GRK5, and GRK6 (all 46-48\% identity) with lower homology to GRK2 and GRK3 (31-32\%).

\section{Role of GRKs in Desensitization}

During the course of the early work on GRKs, another protein that contributes to the regulation of GPCR function was identified. This protein was initially described as a $48 \mathrm{kDa}$ protein that interacted with photoreceptor membranes in a light-dependent manner [41]. This $48 \mathrm{kDa}$ protein was found to be identical to another rod cell protein called S-antigen and was shown to bind to phosphorylated rhodopsin and inhibit rod cGMP phosphodiesterase activity [42-44]. The protein was ultimately named arrestin based on its ability to bind to light-activated rhodopsin and arrest or turn-off phototransduction. A key feature of arrestin was its ability to bind to light-activated rhodopsin that had been phosphorylated by rhodopsin kinase [44]. While similarities between the regulation of phototransduction and hormonal signaling were starting to be established in the mid1980s [21,22], these similarities were extended by efforts supporting a role for an arrestin in desensitizing $\beta_{2}$ AR signaling [45]. These studies found that crude $\beta$ ARK preparations had the ability to phosphorylate purified $\beta_{2} \mathrm{AR}$ and effectively inhibit receptor interaction with purified $\mathrm{G}_{\mathrm{s}}$. $\beta_{2} \mathrm{AR}$ phosphorylation by more highly purified $\beta$ ARK preparations, however, had a modest effect on receptor- $\mathrm{G}_{\mathrm{S}}$ coupling. This suggested the loss of a desensitizationfactor during the $\beta$ ARK purification, and we were able to demonstrate that purified visual arrestin could inhibit $\beta_{2} \mathrm{AR}$ interaction with $\mathrm{G}_{\mathrm{s}}$ in a phosphorylation-dependent manner, albeit at very high stoichiometries [45]. This suggested that the desensitization factor that was lost during the $\beta$ ARK purification was a non-visual arrestin, although our attempts to isolate this factor were unsuccessful. Nevertheless, these efforts ultimately led to the cloning of a non-visual arrestin termed $\beta$-arrestin (now called $\beta$-arrestin- 1 or arrestin-2) that could specifically bind to $\beta$ ARK-phosphorylated $\beta_{2} \mathrm{AR}$ and inhibit receptor interaction with $\mathrm{G}_{\mathrm{s}}$ [46]. Thus, these early studies found that GRKs play a central role in promoting arrestin binding to agonist-activated GPCRs and function to turn off receptor interaction with heterotrimeric $\mathrm{G}$ proteins, a process termed agonist-specific or homologous desensitization. We now know that there are four arrestins, two visual and two non-visual, that coordinate with GRKs to desensitize GPCR signaling through G proteins [47,48]. Moreover, the two non-visual $\beta$-arrestins also play important roles in GPCR trafficking $[49,50]$ as well as arrestin-mediated signaling [51,52], although mechanistic details of these processes remain to be fully defined.

\section{Summary}

While the studies described above highlight some of the initial work identifying the GRK family, we now know much more about the role of GRKs in regulating GPCR function, a topic that has been extensively reviewed over the years [47,48,53-58]. What is left to do? We know a lot about GRKs and GRK activation from structural studies [59-66] and have some mechanistic insight on GRK-GPCR interaction [67,68]. For example, GRK5 binding to the $\beta_{2} \mathrm{AR}$ promotes disruption of an ionic lock between the catalytic and regulator of $G$ protein signaling homology $(\mathrm{RH})$ domains that normally helps to maintain the kinase in a basal state [67], whereas a similar conformational change is observed when calmodulin binds to GRK5, leading to disruption of catalytic-RH domain interaction and kinase activation [69]. However, we still do not know what determines the specificity of GRK-GPCR interaction. We know that GRKs are activated by binding to GPCRs [70,71], but we do not know if this activation solely enhances GPCR phosphorylation or whether it also enhances the phosphorylation of additional substrates. We know that GRKs can phosphorylate many proteins other than GPCRs [55-57,72], but there have been no broadbased proteomic studies to broadly define the GRK phospho-proteome. GRKs have also been implicated in the barcode hypothesis that proposes that different sites of GPCR 
phosphorylation will induce distinct conformations and functions of bound arrestin [73,74], but we know little about the link between specific sites of phosphorylation, the GRK and arrestin involved, and the functional consequences. We also know that GRKs are potential targets in the treatment of several diseases, including cardiovascular disease, metabolic and neurological disorders, and cancer [55-57], but much remains to be learned about the best strategies to target specific GRKs and the side effects that might occur in doing so. We have learned much about GRKs since their initial discovery some 40 plus years ago, but there seems to be plenty left to do.

Funding: This work was funded by National Institutes of Health awards R01GM44944, R35GM122541, R01HL142310, and P01HL114471.

Institutional Review Board Statement: Not applicable.

Informed Consent Statement: Not applicable.

Data Availability Statement: No new data were created or analyzed in this study.

Acknowledgments: J.L.B. would like to thank all past and present fellows who have trained in his laboratory for their many contributions in helping to identify and dissect the function of GRKs.

Conflicts of Interest: The authors declare no conflict of interest.

\section{References}

1. Lefkowitz, R.J. A brief history of G-protein coupled receptors (Nobel Lecture). Angew. Chem. Int. Ed. Engl. 2013, 52, 6366-6378. [CrossRef]

2. Lefkowitz, R.J. Rodbell and Gilman win 1994 Nobel prize for Physiology and Medicine. Trends Pharmacol. Sci. 1994, 15, 442-444. [CrossRef]

3. Kühn, H.; Dreyer, W.J. Light dependent phosphorylation of rhodopsin by ATP. FEBS Lett. 1972, 20, 1-6. [CrossRef]

4. Bownds, D.; Dawes, J.; Miller, J.; Stahlman, M. Phosphorylation of frog photoreceptor membranes induced by light. Nat. New Biol. 1972, 237, 125-127. [CrossRef]

5. Frank, R.N.; Cavanagh, H.D.; Kenyon, K.R. Light-stimulated phosphorylation of bovine visual pigments by adenosine triphosphate. J. Biol. Chem. 1973, 248, 596-609. [CrossRef]

6. Weller, M.; Virmaux, N.; Mandel, P. Light-stimulated phosphorylation of rhodopsin in the retina: The presence of a protein kinase that is specific for photobleached rhodopsin. Proc. Natl. Acad. Sci. USA 1975, 72, 381-385. [CrossRef]

7. Shichi, H.; Somers, R.L. Light-dependent phosphorylation of rhodopsin. Purification and properties of rhodopsin kinase. J. Biol. Chem. 1978, 253, 7040-7046. [CrossRef]

8. Palczewski, K.; McDowell, J.H.; Hargrave, P.A. Purification and characterization of rhodopsin kinase. J. Biol. Chem. 1988, 263, 14067-14072. [CrossRef]

9. Stadel, J.M.; Nambi, P.; Lavin, T.N.; Heald, S.L.; Caron, M.G.; Lefkowitz, R.J. Catecholamine-induced desensitization of turkey erythrocyte adenylate cyclase. Structural alterations in the beta-adrenergic receptor revealed by photoaffinity labeling. J. Biol. Chem. 1982, 257, 9242-9245. [CrossRef]

10. Stadel, J.M.; Nambi, P.; Shorr, R.G.; Sawyer, D.F.; Caron, M.G.; Lefkowitz, R.J. Catecholamine-induced desensitization of turkey erythrocyte adenylate cyclase is associated with phosphorylation of the beta-adrenergic receptor. Proc. Natl. Acad. Sci. USA 1983, 80, 3173-3177. [CrossRef]

11. Sibley, D.R.; Peters, J.R.; Nambi, P.; Caron, M.G.; Lefkowitz, R.J. Desensitization of turkey erythrocyte adenylate cyclase. Betaadrenergic receptor phosphorylation is correlated with attenuation of adenylate cyclase activity. J. Biol. Chem. 1984, 259, 9742-9749. [CrossRef]

12. Shorr, R.G.; Lefkowitz, R.J.; Caron, M.G. Purification of the beta-adrenergic receptor. Identification of the hormone binding subunit. J. Biol. Chem. 1981, 256, 5820-5826. [CrossRef]

13. Shorr, R.G.; Strohsacker, M.W.; Lavin, T.N.; Lefkowitz, R.J.; Caron, M.G. The $\beta_{1}$-adrenergic receptor of the turkey erythrocyte. Molecular heterogeneity revealed by purification and photoaffinity labeling. J. Biol. Chem. 1982, 257, 12341-12350. [CrossRef]

14. Benovic, J.L.; Shorr, R.G.; Caron, M.G.; Lefkowitz, R.J. The mammalian $\beta_{2}$-adrenergic receptor: Purification and characterization. Biochemistry 1984, 23, 4510-4518. [CrossRef] [PubMed]

15. Cerione, R.A.; Strulovici, B.; Benovic, J.L.; Lefkowitz, R.J.; Caron, M.G. The pure beta-adrenergic receptor: A single polypeptide confers catecholamine responsiveness to an adenylate cyclase system. Nature 1983, 306, 562-566. [CrossRef] [PubMed]

16. Cerione, R.A.; Codina, J.; Benovic, J.L.; Lefkowitz, R.J.; Birnbaumer, L.; Caron, M.G. The mammalian $\beta_{2}$-adrenergic receptor: Reconstitution of functional interactions between the pure receptor and the pure stimulatory nucleotide binding protein (Ns) of the adenylate cyclase system. Biochemistry 1984, 23, 4519-4525. [CrossRef] [PubMed] 
17. Dixon, R.A.F.; Kobilka, B.K.; Strader, D.J.; Benovic, J.L.; Dohlman, H.G.; Frielle, T.; Bolanowski, M.A.; Bennett, C.D.; Rands, E.; Diehl, R.E.; et al. Cloning of the gene and cDNA for mammalian beta-adrenergic receptor and homology with rhodopsin. Nature 1986, 321, 75-79. [CrossRef]

18. Benovic, J.L.; Pike, L.J.; Cerione, R.A.; Staniszewski, C.; Yoshimasa, T.; Codina, J.; Birnbaumer, L.; Caron, M.G.; Lefkowitz, R.J. Phosphorylation of the mammalian beta-adrenergic receptor by cyclic AMP-dependent protein kinase: Regulation of the rate of receptor phosphorylation and dephosphorylation by agonist occupancy and effects on coupling of the receptor to the stimulatory guanine nucleotide regulatory protein. J. Biol. Chem. 1985, 260, 7094-7101. [PubMed]

19. Pitcher, J.; Lohse, M.J.; Codina, J.; Caron, M.G.; Lefkowitz, R.J. Desensitization of the isolated beta 2-adrenergic receptor by beta-adrenergic receptor kinase, cAMP-dependent protein kinase, and protein kinase $\mathrm{C}$ occurs via distinct molecular mechanisms. Biochemistry 1992, 31, 3193-3197. [CrossRef]

20. Strasser, R.H.; Sibley, D.R.; Lefkowitz, R.J. A novel catecholamine-activated cyclic 3',5'-phosphate independent pathway for betaadrenergic receptor phosphorylation in wild-type and mutant $\mathrm{S} 49$ lymphoma cells: Mechanism of homologous desensitization of adenylate cyclase. Biochemistry 1986, 25, 1371-1377. [CrossRef]

21. Benovic, J.L.; Strasser, R.H.; Caron, M.G.; Lefkowitz, R.J. Beta-adrenergic receptor kinase: Identification of a novel protein kinase which phosphorylates the agonist-occupied form of the receptor. Proc. Natl. Acad. Sci. USA 1986, 83, 2797-2801. [CrossRef]

22. Lefkowitz, R.J.; Benovic, J.L.; Kobilka, B.K.; Caron, M.G. Receptors and rhodopsin: Shedding new light on an old subject. Trends Pharmacol. Sci. 1986, 7, 444-448. [CrossRef]

23. Benovic, J.L.; Mayor, F., Jr.; Somers, R.L.; Caron, M.G.; Lefkowitz, R.J. Light- dependent phosphorylation of rhodopsin by beta-adrenergic receptor kinase. Nature 1986, 322, 867-872.

24. Strasser, R.H.; Benovic, J.L.; Caron, M.G.; Lefkowitz, R.J. Beta-agonist- and prostaglandin E E $_{1}$ induced translocation of the beta-adrenergic receptor kinase: Evidence that the kinase may act on multiple adenylate cyclase-coupled receptors. Proc. Natl. Acad. Sci. USA 1986, 83, 6362-6366. [CrossRef]

25. Mayor, F., Jr.; Benovic, J.L.; Caron, M.G.; Lefkowitz, R.J. Somatostatin induces translocation of the beta-adrenergic receptor kinase and desensitizes somatostatin receptors in S49 lymphoma cells. J. Biol. Chem. 1987, 262, 6468-6471. [CrossRef]

26. Benovic, J.L.; Regan, J.R.; Matsui, H.; Mayor, F., Jr.; Cotecchia, S.; Leeb-Lundberg, L.M.F.; Caron, M.G.; Lefkowitz, R.J. Agonistdependent phosphorylation of the alpha-2-adrenergic receptor by the beta-adrenergic receptor kinase. J. Biol. Chem. 1987, 262, 17251-17253. [CrossRef]

27. Benovic, J.L.; Mayor, F., Jr.; Staniszewski, C.; Lefkowitz, R.J.; Caron, M.G. Purification and characterization of the beta-adrenergic receptor kinase. J. Biol. Chem. 1987, 262, 9026-9032. [CrossRef]

28. Benovic, J.L.; DeBlasi, A.; Stone, W.C.; Caron, M.G.; Lefkowitz, R.J. Primary structure of the beta-adrenergic receptor kinase delineates a potential multigene family of receptor specific kinases. Science 1989, 246, 235-240. [CrossRef]

29. Benovic, J.L.; Onorato, J.J.; Arriza, J.L.; Stone, W.C.; Lohse, M.; Jenkins, N.; Gilbert, D.J.; Copeland, N.G.; Caron, M.G.; Lefkowitz, R.J. Cloning, expression and chromosomal localization of beta-adrenergic receptor kinase 2: A new member of the receptor kinase family. J. Biol. Chem. 1991, 266, 14939-14946. [CrossRef]

30. Lorenz, W.; Inglese, J.; Palczewski, K.; Onorato, J.J.; Caron, M.G.; Lefkowitz, R.J. The receptor kinase family: Primary structure of rhodopsin kinase reveals similarities to the beta-adrenergic receptor kinase. Proc. Natl. Acad. Sci. USA 1991, 88, 8715-8719. [CrossRef] [PubMed]

31. Inglese, J.; Glickman, J.F.; Lorenz, W.; Caron, M.G.; Lefkowitz, R.J. Isoprenylation of a protein kinase. Requirement of farnesylation/alpha-carboxyl methylation for full enzymatic activity of rhodopsin kinase. J. Biol. Chem. 1992, 267, 1422-1425. [CrossRef]

32. Ambrose, C.; James, M.; Barnes, G.; Lin, C.; Bates, G.; Altherr, M.; Duyao, M.; Groot, N.; Church, D.; Wasmuth, J.J.; et al. A novel G protein-coupled receptor kinase gene cloned from 4p16. 3 Hum. Mol. Genet. 1992, 1, 697-703. [CrossRef] [PubMed]

33. Premont, R.T.; Macrae, A.D.; Stoffel, R.H.; Chung, N.; Pitcher, J.A.; Ambrose, C.; Inglese, J.; MacDonald, M.E.; Lefkowitz, R.J. Characterization of the G protein-coupled receptor kinase GRK4. Identification of four splice variants. J. Biol. Chem. 1996, 271, 6403-6410. [CrossRef]

34. Kunapuli, P.; Benovic, J.L. Cloning and expression of GRK5: A member of the G protein-coupled receptor kinase family. Proc. Natl. Acad. Sci. USA 1993, 90, 5588-5592. [CrossRef] [PubMed]

35. Premont, R.T.; Koch, W.J.; Inglese, J.; Lefkowitz, R.J. Identification, purification, and characterization of GRK5, a member of the family of $G$ protein-coupled receptor kinases. J. Biol. Chem. 1994, 269, 6832-6841. [CrossRef]

36. Cassill, J.A.; Whitney, M.; Joazeiro, C.A.; Becker, A.; Zuker, C.S. Isolation of Drosophila genes encoding G protein-coupled receptor kinases. Proc. Natl. Acad. Sci. USA 1991, 88, 11067-11070. [CrossRef] [PubMed]

37. Benovic, J.L.; Gomez, J. Molecular cloning and expression of GRK6: A new member of the G protein-coupled receptor kinase family. J. Biol. Chem. 1993, 268, 19521-19527. [CrossRef]

38. Haribabu, B.; Snyderman, R. Identification of additional members of human G-protein-coupled receptor kinase multigene family. Proc. Natl. Acad. Sci. USA 1993, 90, 9398-9402. [CrossRef] [PubMed]

39. Weiss, E.R.; Raman, D.; Shirakawa, S.; Ducceschi, M.H.; Bertram, P.T.; Wong, F.; Kraft, T.W.; Osawa, S. The cloning of GRK7, a candidate cone opsin kinase, from cone- and rod-dominant mammalian retinas. Mol. Vis. 1998, 4, 27.

40. Hisatomi, O.; Matsuda, S.; Satoh, T.; Kotaka, S.; Imanishi, Y.; Tokunaga, F. A novel subtype of G-protein-coupled receptor kinase, GRK7, in teleost cone photoreceptors. FEBS Lett. 1998, 424, 159-164. [CrossRef] 
41. Kühn, H. Light-regulated binding of rhodopsin kinase and other proteins to cattle photoreceptor membranes. Biochemistry 1978, 17, 4389-4395. [CrossRef]

42. Kühn, H.; Hall, S.W.; Wilden, U. Light-induced binding of 48-kDa protein to photoreceptor membranes is highly enhanced by phosphorylation of rhodopsin. FEBS Lett. 1984, 176, 473-478. [CrossRef]

43. Pfister, C.; Chabre, M.; Plouet, J.; Tuyen, V.V.; De Kozak, Y.; Faure, J.P.; Kühn, H. Retinal S antigen identified as the 48K protein regulating light-dependent phosphodiesterase in rods. Science 1985, 228, 891-893. [CrossRef]

44. Wilden, U.; Hall, S.W.; Kühn, H. Phosphodiseterase activation by photoexcited rhodopsin is quenched when rhodopsin is phosphorylated and binds the intrinsic 48-kDa protein of rod outer segments. Proc. Natl. Acad. Sci. USA 1986, 83, 1174-1178. [CrossRef]

45. Benovic, J.L.; Kuhn, H.; Weyand, I.; Codina, J.; Caron, M.G.; Lefkowitz, R.J. Functional desensitization of the isolated betaadrenergic receptor by the $\beta$-adrenergic receptor kinase: Potential role of an analog of the retinal protein arrestin (48 $\mathrm{kDa}$ protein). Proc. Natl. Acad. Sci. USA 1987, 84, 8879-8882. [CrossRef] [PubMed]

46. Lohse, M.J.; Benovic, J.L.; Codina, J.; Caron, M.G.; Lefkowitz, R.J. Beta-arrestin: A protein that regulates beta-adrenergic receptor function. Science 1990, 248, 1547-1550. [CrossRef]

47. Krupnick, J.G.; Benovic, J.L. The role of receptor kinases and arrestins in G protein-coupled receptor regulation. Annu. Rev. Pharmacol. Toxicol. 1998, 38, 289-319. [CrossRef]

48. Black, J.B.; Premont, R.T.; Daaka, Y. Feedback regulation of G protein-coupled receptor signaling by GRKs and arrestins. Semin. Cell Dev. Biol. 2016, 50, 95-104. [CrossRef]

49. Ferguson, S.S.; Downey, W.E., 3rd; Colapietro, A.M.; Barak, L.S.; Ménard, L.; Caron, M.G. Role of $\beta$-arrestin in mediating agonist-promoted G protein-coupled receptor internalization. Science 1996, 271, 363-366. [CrossRef] [PubMed]

50. Goodman, O.B., Jr.; Krupnick, J.G.; Santini, F.; Gurevich, V.V.; Penn, R.B.; Gagnon, A.W.; Keen, J.H.; Benovic, J.L. $\beta$-arrestin acts as a clathrin adaptor in endocytosis of the $\beta 2$-adrenergic receptor. Nature 1996, 383, 447-450. [CrossRef]

51. Shukla, A.K.; Xiao, K.; Lefkowitz, R.J. Emerging paradigms of beta-arrestin-dependent seven transmembrane receptor signaling. Trends Biochem. Sci. 2011, 36, 457-469. [CrossRef]

52. Peterson, Y.K.; Luttrell, L.M. The diverse roles of arrestin scaffolds in G protein-coupled receptor signaling. Pharmacol. Rev. 2017, 69, 256-297. [CrossRef] [PubMed]

53. Pitcher, J.A.; Freedman, N.J.; Lefkowitz, R.J. G protein-coupled receptor kinases. Annu. Rev. Biochem. 1998, 67, 653-692. [CrossRef] [PubMed]

54. Premont, R.T.; Gainetdinov, R.R. Physiological roles of G protein-coupled receptor kinases and arrestins. Annu. Rev. Physiol. 2007, 69, 511-534. [CrossRef] [PubMed]

55. Gurevich, E.V.; Tesmer, J.J.; Mushegian, A.; Gurevich, V.V. G protein-coupled receptor kinases: More than just kinases and not only for GPCRs. Pharmacol. Ther. 2012, 133, 40-69. [CrossRef] [PubMed]

56. Hullmann, J.; Traynham, C.J.; Coleman, R.C.; Koch, W.J. The expanding GRK interactome: Implications in cardiovascular disease and potential for therapeutic development. Pharmacol. Res. 2016, 110, 52-64. [CrossRef] [PubMed]

57. Nogués, L.; Reglero, C.; Rivas, V.; Neves, M.; Penela, P.; Mayor, F., Jr. G-protein-coupled receptor kinase 2 as a potential modulator of the hallmarks of cancer. Mol. Pharmacol. 2017, 91, 220-228.

58. Komolov, K.E.; Benovic, J.L. G protein-coupled receptor kinases: Past, present and future. Cell. Signal. 2018, 41, 17-24. [CrossRef]

59. Lodowski, D.T.; Pitcher, J.A.; Capel, W.D.; Lefkowitz, R.J.; Tesmer, J.J.G. Keeping G proteins at bay: A complex between G protein-coupled receptor kinase 2 and G $\beta \gamma$. Science 2003, 300, 1256-1262. [CrossRef]

60. Tesmer, V.M.; Kawano, T.; Shankaranarayanan, A.; Kozasa, T.; Tesmer, J.J. Snapshot of activated G proteins at the membrane: The G $\alpha_{\mathrm{q}}$-GRK2-G $\beta \gamma$ complex. Science 2005, 310, 1686-1690. [CrossRef]

61. Lodowski, D.T.; Tesmer, V.M.; Benovic, J.L.; Tesmer, J.J.G. Crystal structure of G protein-coupled receptor kinase 6 defines the conserved molecular features of the GRK family. J. Biol. Chem. 2006, 281, 16785-16793. [CrossRef]

62. Singh, P.; Wang, B.; Maeda, T.; Palczewski, K.; Tesmer, J.J. Structures of rhodopsin kinase in different ligand states reveal key elements involved in G protein-coupled receptor kinase activation. J. Biol. Chem. 2008, 283, 14053-14062. [CrossRef]

63. Komolov, K.E.; Bhardwaj, A.; Benovic, J.L. Atomic structure of GRK5 reveals distinct structural features novel for G proteincoupled receptor kinases. J. Biol. Chem. 2015, 290, 20629-20647. [CrossRef]

64. Homan, K.T.; Waldschmidt, H.V.; Glukhova, A.; Cannavo, A.; Song, J.; Cheung, J.Y.; Koch, W.J.; Larsen, S.D.; Tesmer, J.J.G. Crystal structure of $\mathrm{G}$ protein-coupled receptor kinase 5 in complex with a rationally designed inhibitor. J. Biol. Chem. 2015, 290, 20649-20659. [CrossRef]

65. Allen, S.J.; Parthasarathy, G.; Darke, P.L.; Diehl, R.E.; Ford, R.E.; Hall, D.L.; Johnson, S.A.; Reid, J.C.; Rickert, K.W.; Shipman, J.M.; et al. Structure and function of the hypertension variant A486V of G protein-coupled receptor kinase 4. J. Biol. Chem. 2015, 290, 23060-23073. [CrossRef] [PubMed]

66. Homan, K.T.; Tesmer, J.J. Structural insights into G protein-coupled receptor kinase function. Curr. Opin. Cell Biol. 2014, $27,25-31$. [CrossRef] [PubMed]

67. Komolov, K.E.; Du, Y.; Duc, N.M.; Betz, R.M.; Rodrigues, J.P.G.L.M.; Leib, R.D.; Patra, D.; Skiniotis, G.; Adams, C.M.; Dror, R.O.; et al. Structural and functional analysis of a $\beta_{2}$-adrenergic receptor complex with GRK5. Cell 2017, 169, 407-412. [CrossRef]

68. He, Y.; Gao, X.; Goswami, D.; Hou, L.; Pal, K.; Yin, Y.; Zhao, G.; Ernst, O.P.; Griffin, P.; Melcher, K.; et al. Molecular assembly of rhodopsin with $G$ protein-coupled receptor kinases. Cell Res. 2017, 27, 728-747. [CrossRef] 
69. Komolov, K.E.; Sulon, S.M.; Bhardwaj, A.; van Keulen, S.C.; Duc, N.M.; Laurinavichyute, D.K.; Lou, H.J.; Turk, B.E.; Chung, K.Y.; Dror, R.O.; et al. Structure of a GRK5-calmodulin complex reveals molecular mechanism of GRK activation and substrate targeting. Mol. Cell 2021, 81, 323-339. [CrossRef] [PubMed]

70. Palczewski, K.; Buczyłko, J.; Kaplan, M.W.; Polans, A.S.; Crabb, J.W. Mechanism of rhodopsin kinase activation. J. Biol. Chem. 1991, 266, 12949-12955. [CrossRef]

71. Chen, C.-Y.; Dion, S.B.; Kim, C.M.; Benovic, J.L. Beta-adrenergic receptor kinase: Agonist-dependent receptor binding promotes kinase activation. J. Biol. Chem. 1993, 268, 7825-7831. [CrossRef]

72. Penela, P.; Ribas, C.; Sánchez-Madrid, F.; Mayor, F., Jr. G protein-coupled receptor kinase 2 (GRK2) as a multifunctional signaling hub. Cell. Mol. Life Sci. 2019, 76, 4423-4446. [CrossRef] [PubMed]

73. Nobles, K.N.; Xiao, K.; Ahn, S.; Shukla, A.K.; Lam, C.M.; Rajagopal, S.; Strachan, R.T.; Huang, T.Y.; Bressler, E.A.; Hara, M.R.; et al. Distinct phosphorylation sites on the $\beta 2$-adrenergic receptor establish a barcode that encodes differential functions of $\beta$-arrestin. Sci. Signal. 2011, 4, ra51. [CrossRef] [PubMed]

74. Latorraca, N.R.; Masureel, M.; Hollingsworth, S.A.; Heydenreich, F.M.; Suomivuori, C.M.; Brinton, C.; Townshend, R.J.L.; Bouvier, M.; Kobilka, B.K.; Dror, R.O. How GPCR phosphorylation patterns orchestrate arrestin-mediated signaling. Cell 2020, 183, 1813-1825. [CrossRef] [PubMed] 